\title{
Towards chemical and nutritional inventory of Portuguese wild edible mushrooms in different habitats
}

\author{
ELIANA PEREIRA $^{\mathrm{a}, \mathrm{b}}$, LILLIAN BARROS $^{\mathrm{a}, \mathrm{b}}$, ANABELA MARTINS $^{\mathrm{a}}$ AND \\ ISABEL C.F.R. FERREIRA ${ }^{a, b, *}$
}

${ }^{a}$ CIMO-ESA, Instituto Politécnico de Bragança, Campus de Santa Apolónia, Apartado 1172, 5301-855 Bragança, Portugal.

${ }^{\mathrm{b}}$ Escola Superior Agrária, Instituto Politécnico de Bragança, Campus de Santa Apolónia, Apartado 1172, 5301-855 Bragança, Portugal.

* Author to whom correspondence should be addressed (e-mail: iferreira@ipb.pt telephone +351-273-303219; fax +351-273-325405). 


\begin{abstract}
Mushrooms have been valued as highly tasty/nutritional foods and as a source of compounds with medicinal properties. The huge mushrooms reservoir of Northeast Portugal must be chemically and nutritionally characterized for the benefit of populations and for the genetic conservation of wild macrofungi. Herein, a chemical, nutritional and bioactive inventory of potentially interesting species (and not yet characterized in literature) from different habitats (Castanea sativa, Pinus sp., Quercus sp., fields and mixed stands) was performed. Besides macronutrients with a wellbalanced proportion, the studied wild mushrooms have also important micronutrients (vitamins) and non-nutrients (phenolics) with bioactive properties such as antioxidant potential. Furthermore, being a source of important antioxidants the wild species, mainly Suillus variegatus (Pinus sp. habitat), Boletus armeniacus (Castanea sativa habitat), Clavariadelphus pistillaris (Quercus sp. habitat), Agaricus lutosus (fields) and Bovista aestivalis (mixed stands), can be used in diet as nutraceuticals and/or functional foods maintaining and promoting health, longevity and life quality.
\end{abstract}

Keywords: Wild edible mushrooms; Chemical inventory; Proximate composition; Fatty acids; Sugars; Vitamins; Antioxidant potential 


\section{Introduction}

Mushrooms past and current uses and practices, represent an important cultural heritage as they are used since immemorial times as food and medicine according to traditional ecological knowledge transmitted along generations. Mushrooms have long been valued as highly tasty/nutritional foods. There are available in literature several studies reporting nutrients analysis of mushrooms from Spain (Díez \& Alvarez, 2001), Finland (Mattila, Salo-Väänänen, Könkö, Aro, \& Jalava, 2002), Greece (Ouzouni, Petridis, Koller, \& Riganakos, 2009), Italy (Manzi, Marconi, Aguzzi, \& Pizzoferrato, 2004), India (Agahar-Murugkar \& Subbulakshmi, 2005), Mexico (Léon-Guzmán, Silva, \& López, 1997), Nigeria (Aletor, 1995), Portugal (Heleno, Barros, Sousa, Martins, \& Ferreira, 2009), Taiwan (Tsai, Tsai, \& Mau, 2008), Tanzania (Mdachi, Nkunya, Nyigo, \& Urasa, 2004) and Turkey (Yildiz, Karakaplan, \& Aydin, 1998). In Europe, wild mushrooms are collected for consumption being a good source of digestible proteins, carbohydrates, fibres and vitamins (Barros, Baptista, Correia, Casal, Oliveira, \& Ferreira, 2007a; Barros, Baptista, Estevinho, \& Ferreira, 2007b; Heleno et al., 2009; Kalač, 2009; Ouzouni et al., 2009). Dry matter content is usually about $100 \mathrm{~g} / \mathrm{kg}$. Structural polysaccharides and proteins comprise the main components of dry matter, while the lipid content is low. Chitin, glycogen, mannitol and trehalose are typical carbohydrate constituents. The proportion of essential amino acids is nutritionally favourable, while the content of n-3 fatty acid is negligible (Kalač, 2009).

Macrofungi traditionally used in gastronomy are mainly mycorrhizal fungi associated with ecologically/economically important trees such as Castanea sativa (Baptista, Martins, Tavares, \& Lino-Neto, 2010), Pinus (Martín-Pinto et al., 2006) and Quercus sp. (Garibay-Orijel et al., 2009). Furthermore, macrofungi have a history of traditional use in oriental therapies and modern clinical practices continue to rely on mushroom- 
derived preparations. They accumulate a variety of bioactive metabolites (e.g. phenolic compounds, polyketides, terpenes, steroids and polysaccharides) with immunomodulatory, cardiovascular, liver protective, anti-fibrotic, anti-inflammatory, anti-diabetic, anti-viral, antimicrobial activities, and antitumor properties (Lindequist, Niedermeyer, \& Jülich, 2005; Poucheret, Fons, \& Rapior, 2006; Zhang, Cui, Cheung, \& Wang, 2007; Ferreira, Vaz, Vasconcelos, \& Martins, 2010). Purified bioactive compounds derived from medicinal mushrooms are a potentially important new source of natural antioxidants that positively influence oxidative stress related diseases such as cancer (Moradali, Mostafavi, Ghods, \& Hedjaroude, 2005; Zaidman, Yassin, Mahajana, \& Wasser, 2005; Valko et al., 2007; Ferreira, Barros, \& Abreu, 2009).

In some fields like the food and pharmaceutical industries mushrooms are an important and valued commodity. In 2004, the estimated value of wild edible mushroom gathering was $\$ 2$ billion (Boa, 2004). Therefore, their chemical and biological characteristics attract significant interest as they are natural bioreactors for production of compounds with human interest for biotechnological applications.

The huge mushrooms reservoir of Northeast Portugal must be chemically/nutritionally characterized for practical sustainable applications in biotechnological systems and industries and for the benefit of populations, while contributing for the genetic conservation of wild macrofungi. Following the work carried out by our research group in order to demonstrate the promising health enhancing properties of mushrooms compounds (Barros et al., 2007a: Barros et al., 2007b; Heleno, Barros, Sousa, Martins, \& Ferreira, 2010; Vaz et al., 2010; Vaz et al., 2011), a chemical/nutritional/bioactive inventory of potentially interesting species (and not yet characterized in literature) from different habitats (Castanea sativa, Pinus sp., Quercus sp., fields and mixed stands) in Northeast Portugal was performed. 


\section{Materials and methods}

\subsection{Samples}

Twenty wild edible mushroom species were collected in Bragança (Northeast Portugal) in different habitats (each habitat corresponds to the same local of collection for the different species), in October/November of 2009 and 2010, according to Table 1. Three to ten specimens of each mushroom species were collected in the maturity stage recommended for consumption. Taxonomic identification of sporocarps was made according to several authors (Benguría, 1985; Phillips, 1988; Galli, 2001; Frade \& Alfonso, 2005; Moreno, 2005), and representative voucher specimens were deposited at the herbarium of School of Agriculture of Polytechnic Institute of Bragança. The specimens of each species were lyophilised (Ly-8-FM-ULE, Snijders, Holland), reduced to a fine dried powder (20 mesh), mixed to obtain an homogenate sample and kept at $20^{\circ} \mathrm{C}$ until further analysis.

\subsection{Standards and Reagents}

Acetonitrile $99.9 \%, n$-hexane $95 \%$ and ethyl acetate $99.8 \%$ were of HPLC grade from Fisher Scientific (Lisbon, Portugal). The fatty acids methyl ester (FAME) reference standard mixture 37 (standard 47885-U) was purchased from Sigma (St. Louis, MO, USA), as also other individual fatty acid isomers, L-ascorbic acid, tocopherols ( $\alpha-, \beta-$, $\gamma$-, and $\delta$-isoforms), sugars (D(-)-fructose, $\mathrm{D}(-)$-mannitol, $\mathrm{D}(+)$-raffinose pentahydrate, and $\mathrm{D}(+)$-trehalose), trolox (6-hydroxy-2,5,7,8-tetramethylchroman-2-carboxylic acid), gallic acid and (+)-catechin standards. Racemic tocol, $50 \mathrm{mg} / \mathrm{ml}$, was purchased from Matreya (PA, USA). 2,2-Diphenyl-1-picrylhydrazyl (DPPH) was obtained from Alfa Aesar 
(Ward Hill, MA, USA). All other chemicals and solvents were of analytical grade and purchased from common sources. Water was treated in a Milli-Q water purification system (TGI Pure Water Systems, USA).

\subsection{Macronutrients}

2.3.1. Nutritional value. The samples were analysed for chemical composition (moisture, proteins, fat, carbohydrates and ash) using the AOAC procedures (AOAC, 1995). The crude protein content $(\mathrm{N} \times 4.38)$ of the samples was estimated by the macroKjeldahl method; the crude fat was determined by extracting a known weight of powdered sample with petroleum ether, using a Soxhlet apparatus; the ash content was determined by incineration at $600 \pm 15{ }^{\circ} \mathrm{C}$. Total carbohydrates were calculated by difference.

2.3.2. Sugars. Free sugars were determined by high performance liquid chromatography coupled to a refraction index detector (HPLC-RI) as described by Heleno et al. (2009), using raffinose as internal standard (IS). The equipment consisted of an integrated system with a pump (Knauer, Smartline system 1000), degasser system (Smartline manager 5000), auto-sampler (AS-2057 Jasco) and a RI detector (Knauer Smartline 2300). Data were analysed using Clarity 2.4 Software (DataApex). The chromatographic separation was achieved with a Eurospher 100-5 $\mathrm{NH}_{2}$ column $(4.6 \times$ $250 \mathrm{~mm}, 5 \mathrm{~mm}$, Knauer) operating at $30^{\circ} \mathrm{C}$ (7971 R Grace oven). The mobile phase was acetonitrile/deionized water, 70:30 (v/v) at a flow rate of $1 \mathrm{ml} / \mathrm{min}$. The compounds were identified by chromatographic comparisons with authentic standards. Quantification was performed using the internal standard method and sugar contents were further expressed in g per $100 \mathrm{~g}$ of dry weight (dw). 
2.3.3. Fatty Acids. Fatty acids were determined by gas-liquid chromatography with flame ionization detection (GC-FID)/capillary column as described previously by the authors (Heleno et al., 2009). The analysis was carried out with a DANI model GC 1000 instrument equipped with a split/splitless injector, a flame ionization detector (FID at $\left.260{ }^{\circ} \mathrm{C}\right)$ and a Macherey-Nagel column $\left(30 \mathrm{~m} \times 0.32 \mathrm{~mm} \mathrm{ID} \times 0.25 \mu \mathrm{m} d_{f}\right)$. The oven temperature program was as follows: the initial temperature of the column was $50{ }^{\circ} \mathrm{C}$, held for $2 \mathrm{~min}$, then a $30^{\circ} \mathrm{C} / \mathrm{min}$ ramp to $125^{\circ} \mathrm{C}, 5^{\circ} \mathrm{C} / \mathrm{min}$ ramp to $160{ }^{\circ} \mathrm{C}, 20^{\circ} \mathrm{C} / \mathrm{min}$ ramp to $180{ }^{\circ} \mathrm{C}, 3^{\circ} \mathrm{C} / \mathrm{min}$ ramp to $200^{\circ} \mathrm{C}, 20^{\circ} \mathrm{C} / \mathrm{min}$ ramp to $220^{\circ} \mathrm{C}$ and held for $15 \mathrm{~min}$. The carrier gas (hydrogen) flow-rate was $4.0 \mathrm{ml} / \mathrm{min}(0.61 \mathrm{bar})$, measured at $50{ }^{\circ} \mathrm{C}$. Split injection (1:40) was carried out at $250{ }^{\circ} \mathrm{C}$. Fatty acid identification was made by comparing the relative retention times of FAME peaks from samples with standards. The results were recorded and processed using CSW 1.7 software (DataApex 1.7) and expressed in relative percentage of each fatty acid.

\subsection{Micronutrients}

2.4.1. Tocopherols. Tocopherols content was determined following a procedure previously described by Heleno et al. (2010), using tocol as IS. The analysis was carried out in the HPLC system described above connected to a fluorescence detector (FP-2020; Jasco) programmed for excitation at $290 \mathrm{~nm}$ and emission at $330 \mathrm{~nm}$. The chromatographic separation was achieved with a Polyamide II normal-phase column $(250 \times 4.6 \mathrm{~mm}$; YMC Waters $)$ operating at $30^{\circ} \mathrm{C}$. The mobile phase used was a mixture of $\mathrm{n}$-hexane and ethyl acetate (70:30, v/v) at a flow rate of $1 \mathrm{ml} / \mathrm{min}$. The compounds were identified by chromatographic comparisons with authentic standards. Quantification was based on the fluorescence signal response, using the internal 
standard method, and tocopherols contents were further expressed in mg per $100 \mathrm{~g}$ of dry weight (dw).

2.4.2. Ascorbic acid. Ascorbic acid was determined following a procedure previously described by the authors (Grangeia, Heleno, Barros, Martins, \& Ferreira, 2011) with 2,6-dichloroindophenol, and measuring the absorbance at $515 \mathrm{~nm}$ (spectrophotometer AnalytikJena). Content of ascorbic acid was calculated on the basis of the calibration curve of authentic L-ascorbic acid $(0.006-0.1 \mathrm{mg} / \mathrm{ml})$, and the results were expressed as mg of ascorbic acid per $100 \mathrm{~g}$ of dry weight (dw).

2.4.3. Carotenoids. $\beta$-carotene and lycopene were determined following a procedure previously described by the authors (Grangeia et al., 2011), measuring the absorbance at 453, 505, 645, and $663 \mathrm{~nm}$. Contents were calculated according to the following equations: $\beta$-carotene $(\mathrm{mg} / 100 \mathrm{ml})=0.216 \times \mathrm{A}_{663}-1.220 \times \mathrm{A}_{645}-0.304 \times \mathrm{A}_{505}+0.452$ $\times \mathrm{A}_{453} ;$ Lycopene $(\mathrm{mg} / 100 \mathrm{ml})=-0.0458 \times \mathrm{A}_{663}+0.204 \times \mathrm{A}_{645}-0.304 \times \mathrm{A}_{505}+0.452$ $\times \mathrm{A}_{453}$, and further expressed in mg per $100 \mathrm{~g}$ of dry weight $(\mathrm{dw})$.

\subsection{Non-nutrients and in vitro antioxidant properties}

2.5.1. Extraction procedure. A fine dried powder ( $20 \mathrm{mesh} ; 1 \mathrm{~g})$ stirring with $50 \mathrm{ml}$ of methanol at $25^{\circ} \mathrm{C}$ at $150 \mathrm{rpm}$ for $1 \mathrm{~h}$ and filtered through Whatman No. 4 paper. The residue was then extracted with one additional $50 \mathrm{ml}$ portion of methanol. The combined methanolic extracts were evaporated at $35^{\circ} \mathrm{C}$ under reduced pressure (rotary evaporator Büchi R-210), re-dissolved in methanol at $50 \mathrm{mg} / \mathrm{ml}$, and stored at $4{ }^{\circ} \mathrm{C}$ for further analysis of bioactive compounds and antioxidant properties according to procedures described by Heleno et al. (2010). 
2.5.2. Phenolics. Phenolics were determined by Folin-Ciocalteu assay. The extract solution $(1 \mathrm{ml})$ was mixed with Folin-Ciocalteu reagent $(5 \mathrm{ml}$, previously diluted with water $1: 10, \mathrm{v} / \mathrm{v})$ and sodium carbonate $(75 \mathrm{~g} / \mathrm{l}, 4 \mathrm{ml})$. The tubes were vortex mixed for $15 \mathrm{~s}$ and allowed to stand for $30 \mathrm{~min}$ at $40{ }^{\circ} \mathrm{C}$ for colour development. Absorbance was then measured at $765 \mathrm{~nm}$. Gallic acid was used to obtain the standard curve (0.0094$0.15 \mathrm{mg} / \mathrm{ml}$ ), and the results were expressed as $\mathrm{mg}$ of gallic acid equivalents (GAE) per g of extract.

2.5.3. Flavonoids. For flavonoids quantification, the extract sample concentrated at 2.5 $\mathrm{mg} / \mathrm{ml}(0.5 \mathrm{ml})$ was mixed with distilled water $(2 \mathrm{ml})$ and $\mathrm{NaNO}_{2}$ solution $(5 \%, 0.15$ ml). After $6 \mathrm{~min}, \mathrm{AlCl}_{3}$ solution $(10 \%, 0.15 \mathrm{ml})$ was added and allowed to stand further $6 \mathrm{~min}$. $\mathrm{NaOH}$ solution $(4 \%, 2 \mathrm{ml})$ was added to the mixture, followed by distilled water until a final volume of $5 \mathrm{ml}$. The mixture was properly mixed and allowed to stand for $15 \mathrm{~min}$. The intensity of pink colour was measured at $510 \mathrm{~nm}$. (+)-Catechin was used to calculate the standard curve $(0.015-1.0 \mathrm{mM})$ and the results were expressed as $\mathrm{mg}$ of (+)-chatequin equivalents (CE) per g of extract.

2.5.4. DPPH radical-scavenging activity. This methodology was performed using an ELX800 Microplate Reader (Bio-Tek). The reaction mixture in each one of the 96-wells consisted of one of the different concentrations of the extracts $(30 \mu \mathrm{l})$ and aqueous methanolic solution $(80: 20 \mathrm{v} / \mathrm{v}, 270 \mu \mathrm{l})$ containing DPPH radicals $\left(6 \times 10^{-5} \mathrm{~mol} / \mathrm{l}\right)$. The mixture was left to stand for 60 min in the dark. The reduction of the DPPH radical was determined by measuring the absorption at $515 \mathrm{~nm}$. The radical scavenging activity (RSA) was calculated as a percentage of DPPH discolouration using the equation: \% 
RSA $=\left[\left(A_{D P P H}-A_{S}\right) / A_{D P P H}\right] \times 100$, where $A_{S}$ is the absorbance of the solution when the sample extract has been added at a particular level, and $\mathrm{A}_{\mathrm{DPPH}}$ is the absorbance of the DPPH solution. The extract concentration providing $50 \%$ of radicals scavenging activity $\left(\mathrm{EC}_{50}\right)$ was calculated from the graph of RSA percentage against extract concentration. Trolox was used as standard.

2.5.5. Reducing power. This methodology was performed using the Microplate Reader described above. The different concentrations of the extracts $(0.5 \mathrm{ml})$ were mixed with sodium phosphate buffer $(200 \mathrm{mmol} / \mathrm{l}, \mathrm{pH} 6.6,0.5 \mathrm{ml})$ and potassium ferricyanide $(1 \%$ w/v, $0.5 \mathrm{ml}$ ). The mixture was incubated at $50{ }^{\circ} \mathrm{C}$ for $20 \mathrm{~min}$, and trichloroacetic acid $(10 \% \mathrm{w} / \mathrm{v}, 0.5 \mathrm{ml})$ was added. The mixture $(0.8 \mathrm{ml})$ was poured in the 48 -wells, as also deionised water $(0.8 \mathrm{ml})$ and ferric chloride $(0.1 \% \mathrm{w} / \mathrm{v}, 0.16 \mathrm{ml})$, and the absorbance was measured at $690 \mathrm{~nm}$. The extract concentration providing 0.5 of absorbance $\left(\mathrm{EC}_{50}\right)$ was calculated from the graph of absorbance at $690 \mathrm{~nm}$ against extract concentration. Trolox was used as standard.

2.5.6. Inhibition of $\beta$-carotene bleaching. A solution of $\beta$-carotene was prepared by dissolving $\beta$-carotene $(2 \mathrm{mg})$ in chloroform $(10 \mathrm{ml})$. Two millilitres of this solution were pipetted into a round-bottom flask. After the chloroform was removed at $40^{\circ} \mathrm{C}$ under vacuum, linoleic acid (40 mg), Tween 80 emulsifier (400 mg), and distilled water $(100 \mathrm{ml})$ were added to the flask with vigorous shaking. Aliquots $(4.8 \mathrm{ml})$ of this emulsion were transferred into different test tubes containing different concentrations of the extracts $(0.2 \mathrm{ml})$. The tubes were shaken and incubated at $50^{\circ} \mathrm{C}$ in a water bath. As soon as the emulsion was added to each tube, the zero time absorbance was measured at $470 \mathrm{~nm}$. $\beta$-Carotene bleaching inhibition was calculated using the following equation: 
$(\beta$-carotene content after $2 \mathrm{~h}$ of assay/initial $\beta$-carotene content $) \times 100$. The extract concentration providing $50 \%$ antioxidant activity $\left(\mathrm{EC}_{50}\right)$ was calculated by interpolation from the graph of $\beta$-carotene bleaching inhibition percentage against extract concentration. Trolox was used as standard.

\subsection{Statistical analysis}

For each sample three extracts were obtained and all the assays were carried out in triplicate. The results are expressed as mean values and standard deviation (SD). The results were analyzed using one-way analysis of variance (ANOVA) followed by Tukey's HSD Test with $\alpha=0.05$. This treatment was carried out using SPSS v. 16.0 program.

\section{Results}

The results of the macronutrients composition obtained for the studied wild edible mushrooms are shown in Table 2. Moisture ranges between $72 \mathrm{~g} / 100 \mathrm{~g}$ fw in Boletus armeniacus and $92 \mathrm{~g} / 100 \mathrm{~g}$ fw in Hygrophorus chrysodon. The highest levels of protein were found in Agaricus lutosus $(23 \mathrm{~g} / 100 \mathrm{~g} \mathrm{dw})$. Lycoperdon umbrinum (33 g/100 g $\mathrm{dw})$ and Bovista aestivalis (32 $\mathrm{g} / 100 \mathrm{~g} \mathrm{dw})$ revealed the highest ash contents without significant statistical differences $(p<0.05)$. Otherwise, these two mushrooms gave the lowest fat levels $(<0.2 \mathrm{~g} / 100 \mathrm{~g} \mathrm{dw})$. Carbohydrates, calculated discounting protein and fat levels, were the most abundant macronutrients and the highest levels were found in Ramaria aurea $(77 \mathrm{~g} / 100 \mathrm{~g} \mathrm{dw})$. Carbohydrates content includes also fibre. Information on dietary fibre content in wild mushrooms ranged between $4.2-9.2 \%$ and $22.4-31.2 \%$ of dry matter for soluble and insoluble fibre, respectively. In fact, mushrooms contain structural polysaccharides such as chitin, hemicelluloses and pectic substances (Kalac, 
2009). Herein, we focused in the analysis of individual molecules that could supply energy to the human body (such as sugars and fatty acids) in order to recommend the use of mushrooms from a nutritional point of view. Particularly sugars, mainly mannitol and trehalose, are abundant carbohydrates in the wild edible mushrooms (Table 2). The species where fructose was found are all mycorrhizal, which is in agreement with our previous results (Grangeia et al., 2011). Cortinarius praestans revealed the highest total sugars content $(61 \mathrm{~g} / 100 \mathrm{~g} \mathrm{dw})$, with the highest levels of trehalose $(60 \mathrm{~g} / 100 \mathrm{~g} \mathrm{dw})$.

The results of the main fatty acids found in the studied wild mushrooms, as also their saturated fatty acids (SFA), monounsaturated fatty acids (MUFA) and polyunsaturated fatty acids (PUFA) percentages are shown in Table 3. Up to twenty-seven fatty acids were detected in most of the samples (data not shown). The major fatty acid found was linoleic acid (C18:2n6) (prevalence of PUFA), unless for Hygrophorus chrysodon, Suillus variegatus, Clavariadelphus pistillaris, Ramaria aurea, Amanita umbrinolutea, Clavariadelphus truncatus and Clitocybe costata where oleic acid (C18:1n9) predominated, contributing to the prevalence of MUFA in those species. The studied species also revealed palmitic acid (C16:0) as a major fatty acid. Agaricus comtulus, Agaricus lutosus, Leucoagaricus leucothites and Chlorophyllum rhacodes gave the highest levels of PUFA (72-75\%), while Hygrophorus chrysodon gave the highest levels of MUFA (63\%).

Micronutrients such as vitamins and carotenoids contents were determined and the results are given in Table 4. Ascorbic acid was not found in Boletus armeniacus, Lycoperdon umbrinum, Agaricus comtulus, Bovista aestivalis, Bovista nigrescens, Chlorophyllum rhacodes and Clitocybe costata. Nevertheless, in the other mushroom species it was more abundant than tocopherols. Agaricus lutosus and Hygrophorus chrysodon revealed the highest ascorbic acid concentration $(\sim 30 \mathrm{mg} / 100 \mathrm{~g} \mathrm{dw})$. 
Lycoperdon umbrinum presented the highest content of tocopherols $(1.7 \mathrm{mg} / 100 \mathrm{~g} \mathrm{dw})$ with the highest levels of $\alpha-(1.5 \mathrm{mg} / 100 \mathrm{~g} \mathrm{dw})$ and $\beta-(0.1 \mathrm{mg} / 100 \mathrm{~g} \mathrm{dw})$ isoforms. Suillus variegatus revealed the highest concentration of $\gamma$-tocopherol $(1.4 \mathrm{mg} / 100 \mathrm{~g} \mathrm{dw})$. Carotenois were found in low amounts; the highest levels of $\beta$-carotene and lycopene were observed in Agaricus campestris and Ramaria aurea, respectively $(<1 \mathrm{mg} / 100 \mathrm{~g}$ $\mathrm{dw})$.

The composition in non-nutrients and in vitro antioxidant activity of the studied wild mushrooms is shown in Table 5. Suillus variegatus gave the best results in all the antioxidant activity assays (DPPH scavenging activity, reducing power and $\beta$-carotene bleaching inhibition) with $\mathrm{EC}_{50}$ values $\leq 1 \mathrm{mg} / \mathrm{ml}$. This is in agreement to its highest levels of phenolics (58 mg GAE/g extract) and flavonoids (33 mg CE/g extract). Otherwise, Hygrophorus chrysodon revealed the lowest antioxidant properties $\left(\mathrm{EC}_{50}\right.$ values ranging from 6 to $20 \mathrm{mg} / \mathrm{ml}$ ) and also the lowest phenolics (5 mg GAE/g extract) and flavonoids concentrations (2 mg CE/g extract).

Besides Suillus variegatus from Pinus sp. habitat, there are other mushrooms with high antioxidant activity and that revealed increasing effects with the increase of extract concentration, as can be observed in Figure 1: Boletus armeniacus (Castanea sativa habitat), Clavariadelphus pistillaris (Quercus sp. habitat), Agaricus lutosus (fields) and Bovista aestivalis (mixed stands).

\section{Discussion}

Mushrooms are widely appreciated for their unique taste and flavour, but also for their chemical and nutritional properties (Kalač, 2009). We proved that wild mushrooms from different habitats have high moisture, proteins and carbohydrates contents, in contrast to low fat levels, which make them suitable to incorporate low caloric diets. 
These results are in agreement to different studies reported by us (Barros et al., 2007a; Barros et al., 2007b; Barros, Venturini, Baptista, Estevinho, \& Ferreira, 2008; Heleno et al., 2009; Grangeia et al., 2011) and by other authors (Ouzouni et al., 2009; Kalač, 2009).

The proximate composition of Croatian Agaricus campestris and Flammulina velutipes was recently reported by Beluhan \& Ranogajec (2011). Despite the similar energetic contribution, the Portuguese samples studied by us revealed lower protein and fat contents but higher ash and carbohydrate levels. The observed results could be due to differences in the maturity stage of Croatian and Portuguese fruiting bodies as demonstrated by us in a previous study, where it was observed an increase in protein levels and a decrease in carbohydrate contents with the increase of the maturity (Barros et al., 2007b).

Mannitol and trehalose were the main sugars in the studied mushrooms. Beluhan \& Ranogajec (2011) reported also the presence of mannose and glucose in Croatian Agaricus campestris and Flammulina velutipes. Nevertheless, we could not find these sugars in our samples, as can be observed in Figure 2 for Agaricus campestris.

The alcohols derivatives of sugars, mostly mannitol, are responsible for the support and expansion of mushrooms fruiting bodies (Barros et al., 2008). In fact, sugars are central in cellular energetic metabolism and can also be used in the synthesis of storage or structural polysaccharides (Lehninger, Nelson, \& Cox, 2008). Sugars are only a small part of total carbohydrates, being wild mushrooms rich in polysaccharides such as glycogen and $\beta$-glucans (Kalač, 2009).

The main fatty acids found in the studied wild mushrooms, linoleic and oleic acids, are common in eukaryotic organisms such as fungi. Otherwise, palmitic acid is common to different organisms. Linoleic acid is an essential fatty acid to mammals, and therefore, 
could be supplied in diet through mushrooms. It is precursor of arachidonic acid and of prostaglandins biosynthesis, which play important physiologic activities (Lehninger et al., 2008). Linoleic acid is also precursor of 1-octen-3-ol, known as "fungi alcohol", the main aromatic component in fungi (Maga, 1981). As stated by us and by other authors, UFA were higher than SFA levels (Yilmaz, Solmaz, Turkekul, \& Elmastas, 2006; Kalač, 2009; Heleno et al., 2009; Ouzouni et al., 2009; Grangeia et al., 2011; Lee et al., 2011). In particular, the UFA oleic and linoleic acids were also reported as main fatty acids in Agaricus campestris from Turkey (Yilmaz et al., 2006) and Flammulina velupites from Korea (Lee et al., 2011). As it was observed for the samples of Agaricus campestris and Flammulina velupites herein studied, those authors also observed higher amounts of linoleic acid than oleic acid.

Besides macronutrients, the studied wild mushrooms have also important micronutrients (e.g. vitamins) and non-nutrients (e.g. phenolics) with bioactive properties such as antioxidant potential. Those molecules seem to play a protective role in diseases related to oxidative stress, such as cancer and cardiovascular diseases (Ferreira et al., 2009; Ferreira et al., 2010). In fact, the studied species with relevance for Suillus variegatus (Pinus sp. habitat), Boletus armeniacus (Castanea sativa habitat), Clavariadelphus pistillaris (Quercus sp. habitat), Agaricus lutosus (fields) and Bovista aestivalis (mixed stands), demonstrated capacity to scavenge free radicals such as DPPH, high reducing power and capacity to inhibit lipid peroxidation in a $\beta$-carotene-linoleate system, after neutralization of the linoleate-free radical and other free radicals formed in the system which attack the highly unsaturated $\beta$-carotene models. As far as we know, the antioxidant potential of the studied species was not previously reported, unless Flammulina velutipes (in hydrophilic extracts of a sample from Japan; Bao, Ochiai, \& Ohshima, 2010). The medicinal potential of this particular mushroom has been 
demonstrated due to the antitumor properties of different compounds: the protein flammulin, the polysaccharides galactomannoglucan and riboglucan, the isoflavone genistein and selenium (Ferreira et al., 2010).

In conclusion, wild mushrooms from different habitats are nutritionally well-balanced foods (high carbohydrate and protein levels and low fat concentration), and based on their antioxidant potential and bioactive compounds (vitamins and phenolics) they might find applications in the prevention of free radical-related diseases. Despite being collected in different habitats, the studied mushrooms revealed similar profiles of macronutrients, micronutrients and non-nutrients. The differences observed in their concentrations are certainly due to the species rather than to the habitat. To understand the specific influence of habitat, the same species should be collect in different habitats and further analysed.

The present study contributes to the nutritional and chemical characterization of wild species, making available an inventory to be disseminated in order to promote the consumption of wild edible mushrooms and to conserve their habitats. Furthermore, being a source of important antioxidants the wild species can be used in diet as nutraceuticals and/or functional foods maintaining and promoting health, longevity and life quality.

\section{Acknowledgements}


The authors are grateful to Fundação para a Ciência e a Tecnologia (FCT, Portugal) and COMPETE/QREN/EU (research project PTDC/AGR-ALI/110062/2009) for financial support. L. Barros also thanks to FCT, POPH-QREN and FSE for her grant (SFRH/BPD/4609/2008). The authors thank to Maria João Sousa and Sandrina Heleno for mushrooms collection and identification.

\section{References}

Agahar-Murugkar, D., \& Subbulakshmi, G. (2005). Nutritional value of edible wild mushrooms collected from the Khasi hills of Meghalaya. Food Chemistry, 89, 599-603.

Aletor, V.A. (1995). Compositional studies on edible tropical species of mushrooms. Food Chemistry, 54, 265-268.

AOAC (1995). Official methods of analysis $\left(16^{\text {th }}\right.$ Ed.). Arlington VA, USA: Association of Official Analytical Chemists.

Bao, H.N.D, Ochiai, Y., \& Ohshima, T. (2010). Antioxidative activities of hydrophilic extracts prepared from the fruiting body and spent culture medium of Flammulina velutipes. Bioresource Technology, 101, 6248-6255.

Baptista, P., Martins, A., Tavares, R.M., \& Lino-Neto, T. (2010). Diversity and fruiting pattern of macrofungi associated with chestnut (Castanea sativa) in the Trás-osMontes region (Northeast Portugal). Fungal Ecology, 3, 9-19.

Barros, L., Baptista, P., Correia, D.M., Casal, S., Oliveira, B., \& Ferreira, I.C.F.R. (2007a). Fatty acid and sugar compositions, and nutritional value of five wild edible mushrooms from Northeast Portugal. Food Chemistry, 105, 140-145.

Barros, L. Baptista, P. Estevinho, L.M., \& Ferreira, I.C.F.R. (2007b). Effect of fruiting body maturity stage on chemical composition and antimicrobial activity of 
Lactarius sp. mushrooms. Journal of Agricultural and Food Chemistry, 55, 87668771.

Barros, L., Venturini, B.A., Baptista, P., Estevinho, L.M., \& Ferreira, I.C.F.R. (2008). Chemical composition and biological properties of Portuguese wild mushrooms: A comprehensive study. Journal of Agricultural and Food Chemistry, 56, 38563862.

Beluhan, S., \& Ranogajec, A. (2011). Chemical composition and non-volatile components of Croatian wild edible mushrooms. Food Chemistry, 124, 10761082.

Benguría, R.L. (1985). Mil Setas Ibericas. Diputacion De Vizcaya.

Boa, E. (2004). Los hongos silvestres comestibiles; Perspectiva global de su uso e importancia para la población. FAO, Rome.

Díez, V.A., \& Alvarez, A. (2001). Compositional and nutritional studies on two wild edible mushrooms from northwest Spain. Food Chemistry, 75, 417-422.

Ferreira, I.C.F.R., Barros, L., \& Abreu, R.M.V. (2009). Antioxidants in wild mushrooms. Current Medicinal Chemistry, 16, 1543-1560.

Ferreira, I.C.F.R., Vaz, J.A., Vasconcelos, M.H., \& Martins, A. (2010). Compounds from wild mushrooms with antitumor potential. Anti-cancer Agents in Medicinal Chemistry, 10, 424-436.

Frade, B.L., \& Alfonso, A.T. (2005). Guía de Campo de los Hongos de la Península Ibérica. Celarayn Editorial, León.

Galli, R. (2001). Le Amanite. Edinatura, Milano.

Garibay-Orijel, R., Córdova, J., Cifuentes, J., Valenzuela, R., Estrada-Torres, A., \& Kong, A. (2009). Integrating wild mushrooms use into a model of sustainable 
management for indigenous community forests. Forest Ecology and Management, $258,122-131$.

Grangeia, C., Heleno, S.A. Barros, L., Martins, A., \& Ferreira, I.C.F.R. (2011). Effects of trophism on nutritional and nutraceutical potential of wild edible mushrooms. Food Research International, doi:10.1016/j.foodres.2011.03.006.

Heleno, S.A., Barros, L., Sousa, M.J., Martins, A., \& Ferreira, I.C.F.R. (2009). Study and characterization of selected nutrients in wild mushrooms from Portugal by gas chromatography and high performance liquid chromatography. Microchemical Journal, 93, 195-199.

Heleno, S.A., Barros, L., Sousa, M.J., Martins, A., \& Ferreira, I.C.F.R. (2010). Tocopherols composition of Portuguese wild mushrooms with antioxidant capacity. Food Chemistry, 119, 1443-1450.

Kalač, P. (2009). Chemical composition and nutritional value of European species of wild growing mushrooms: A review. Food Chemistry, 113, 9-16.

Lee, K.J., Yun, I.J., Kim, K.H., Lim, S.H., Ham, H.J., Eum W.S., \& Joo, J.H. (2011). Amino acid and fatty acid compositions of Agrocybe chaxingu, an edible mushroom. Journal of Food Composition and Analysis, doi:10.1016/j.jfca.2010.09.011.

Lehninger, A.L., Nelson, D.L., \& Cox, M.M. (2008). Principles of Biochemistry. W.H. Freeman, $5^{\text {th }}$ edition.

Léon-Guzmán, M.F., Silva, I., \& López, M.G. (1997). Proximate chemical composition, free amino acid contents, and free fatty acids contents of some wild edible mushrooms from Querétaro, México. Journal of Agricultural and Food Chemistry, 45, 4329-4332. 
Lindequist, U., Niedermeyer, T.H.J., \& Jülich, W.-D. (2005). The pharmacological potential of mushrooms. eCAM, 2, 285-299.

Maga, J.A. (1981). Mushroom flavor. Journal of Agricultural and Food Chemistry, 29, $4-7$.

Manzi, P., Marconi, S., Aguzzi, A., \& Pizzoferrato, L. (2004). Commercial mushrooms: nutritional quality and effect of cooking. Food Chemistry, 84, 201-206.

Martín-Pinto, P., Vaquerizo, H., Peñalver, F., Olaizola, J., \& Oria-de-Rueda, J.A. (2006). Early effects of a wildfire on the diversity and production of fungal communities in Mediterranean vegetation types dominated by Cistus ladanifer and Pinus pinaster in Spain. Forest Ecology and Management, 225, 296-305.

Mattila, P., Salo-Väänänen, P., Könkö, K., Aro, H., \& Jalava, T. (2002). Basic composition and amino acid contents of mushrooms cultivated in Finland. Journal of Agricultural and Food Chemistry, 50, 6419-6422.

Mdachi, S.J.M., Nkunya, M.H.H., Nyigo, V.A., \& Urasa, I.T. (2004). Amino acid composition of some Tanzanian wild mushrooms. Food Chemistry, 86, 179-182.

Moradali, M.-F., Mostafavi, H., Ghods, S., \& Hedjaroude, G.-A. (2007). Immunomodulating and anticancer agents in the realm of macromycetes fungi (macrofungi). International Immunopharmacology, 7, 701-724.

Moreno, A.C. (2005). Setas y Hongos de La Rioja II. Fundación Caja Rioja, Logroño.

Ouzouni, P.K., Petridis, D., Koller, W.-D., \& Riganakos, K.A. (2009). Nutritional value and metal content of wild edible mushrooms collected from West Macedonia and Epirus, Greece. Food Chemistry, 115, 1575-1580.

Phillips, R. (1988). Mushrooms and other fungi of Great Britain \& Europe. Macmillan, Oxford. 
Poucheret, P., Fons, F., \& Rapior, S. (2006). Biological and pharmacological activity of higher fungi: 20-Year retrospective analysis. Mycologie, 27, 311-333.

Tsai, S.-Y., Tsai, H.-L., \& Mau, J.-L. (2008). Non-volatile taste components of Agaricus blazei, Agrocybe cylindracea and Boletus edulis. Food Chemistry, 107, 977-983.

Valko, M., Leibfritz, D., Moncol, J., Cronin, M.T.D., Mazur, M., \& Telser J. (2007). Free radicals and antioxidants in normal physiological functions and human disease. International Journal of Biochemistry and Cell Biology, 39, 44-84.

Vaz, J.A., Barros, L., Martins, A., Morais, J.S., Vasconcelos, M.H., \& Ferreira, I.C.F.R. (2011). Phenolic profile of seventeen Portuguese wild mushrooms. LWT-Food Science and Technology, 44, 343-346.

Vaz, J.A., Heleno, S.A., Martins, A., Almeida, G.M., Vasconcelos, M.H., \&. Ferreira I.C.F.R. (2010). Wild mushrooms Clitocybe alexandri and Lepista inversa: In vitro antioxidant activity and growth inhibition of human tumour cell lines. Food and Chemical Toxicology, 48, 2881-2884.

Yildiz, A., Karakaplan, M., \& Aydin, F. (1998). Studies on Pleurotus ostreatus (Jacq. ex Fr.) Kum. Var. salignus (Pers. ex Fr.) Konr. et Maubl.: cultivation, proximate composition, organic and mineral composition of carpophores. Food Chemistry, $61,127-130$.

Zaidman, B.-Z., Yassin, M., Mahajana, J., \& Wasser, S.P. (2005). Medicinal mushroom modulators of molecular targets as cancer therapeutics. Applied Microbiology and Biotechnology, 67, 453-468.

Zhang, M., Cui, S.W., Cheung, P.C.K., \& Wang, Q. (2007). Antitumor polysaccharides from mushrooms: A review on their isolation process, structural characteristics and antitumor activity. Trends in Food Science and Technology, 18, 4-19. 
Yilmaz, N., Solmaz, M., Turkekul, I., \& Elmastas, M. (2006). Fatty acid composition in some wild edible mushrooms growing in the middle Black Sea region of Turkey. Food Chemistry, 99, 168-174. 
Table 1. Information about the wild edible species analysed.

\begin{tabular}{|c|c|c|c|c|}
\hline Scientific name & English name & Habitat & Ecology & Date of collection \\
\hline Boletus armeniacus Quél. & None & Castanea sativa & Mycorrhizal & November 2010 \\
\hline Clitocybe gibba (Pers.) Kumm & Common funnel cap & Pinus sp. & Saprotrophic & November 2009 \\
\hline Hygrophorus chrysodon (Fr.) Fr. & None & Pinus sp. & Saprotrophic & November 2010 \\
\hline Lycoperdon umbrinum Pers. & Umber-brown puffball & Pinus sp. & Saprotrophic & October 2010 \\
\hline Suillus variegatus (Sw.) Kuntze & Velvet bolete & Pinus sp. & Mycorrhizal & October 2010 \\
\hline Boletus impolitus Fr. & Iodine bolete & Quercus sp. & Mycorrhizal & November 2010 \\
\hline Clavariadelphus pistillaris (L.:Fr.) Donk & Pestle-shaped coral & Quercus sp. & Mycorrhizal & October 2010 \\
\hline Ramaria aurea (Schaeff.) Quél. & Golden coral & Quercus sp. & Mycorrhizal & November 2010 \\
\hline Agaricus campestris $(\mathrm{L})$. & Field mushroom & Fields & Saprotrophic & October 2010 \\
\hline Agaricus comtulus Fries & None & Fields & Saprotrophic & October 2010 \\
\hline Agaricus lutosus (Møller) Møller & None & Fields & Saprotrophic & November 2010 \\
\hline Leucoagaricus leucothites Vittad. Wasser & Smooth parasol mushroom & Fields & Saprotrophic & October 2010 \\
\hline Amanita umbrinolutea (Secr. ex Gillet) & Unknown & Mixed stands & Mycorrhizal & October 2010 \\
\hline Bovista aestivalis (Bonord.) Demoulin & None & Mixed stands & Saprotrophic & November 2010 \\
\hline Bovista nigrescens (Pers.) & Brown puffball & Mixed stands & Saprotrophic & November 2010 \\
\hline Chlorophyllum rhacodes (Vittadini) Vellinga & Shaggy parasol & Mixed stands & Saprotrophic & October 2010 \\
\hline Clavariadelphus truncatus (Quel.) Donk & Club Coral & Mixed stands & Mycorrhizal & November 2010 \\
\hline Clitocybe costata Kühner \& Romagn & None & Mixed stands & Saprotrophic & October 2010 \\
\hline Cortinarius Praestans Cordier & Goliath webcap & Mixed stands & Mycorrhizal & October 2010 \\
\hline Flammulina velutipes (Curtis) Singer & Golden needle mushroom & Mixed stands & Saprotrophic & November 2010 \\
\hline
\end{tabular}


Table 2. Macronutrients composition of the wild edible mushrooms.

\begin{tabular}{|c|c|c|c|c|c|c|c|c|c|}
\hline & $\begin{array}{l}\text { Moisture } \\
(\mathrm{g} / 100 \mathrm{~g} \mathrm{fw})\end{array}$ & $\begin{array}{c}\text { Ash } \\
(\mathrm{g} / 100 \mathrm{~g} \mathrm{dw})\end{array}$ & $\begin{array}{c}\text { Proteins } \\
(\mathrm{g} / 100 \mathrm{~g} \mathrm{dw})\end{array}$ & $\begin{array}{c}\text { Fat } \\
(\mathrm{g} / 100 \mathrm{~g} \mathrm{dw})\end{array}$ & $\begin{array}{c}\text { Carbohydrates } \\
(\mathrm{g} / 100 \mathrm{~g} \mathrm{dw})\end{array}$ & $\begin{array}{c}\text { Fructose } \\
(\mathrm{g} / 100 \mathrm{~g} \mathrm{dw})\end{array}$ & $\begin{array}{c}\text { Mannitol } \\
(\mathrm{g} / 100 \mathrm{~g} \mathrm{dw})\end{array}$ & $\begin{array}{l}\text { Trehalose } \\
(\mathrm{g} / 100 \mathrm{~g} \mathrm{dw})\end{array}$ & $\begin{array}{l}\text { Total Sugars } \\
(\mathrm{g} / 100 \mathrm{~g} \mathrm{dw})\end{array}$ \\
\hline Boletus armeniacus & $71.50 \pm 0.43$ & $12.09 \pm 0.35 \mathrm{~h}$ & $18.25 \pm 0.06 \mathrm{edf}$ & $1.56 \pm 0.42$ ih & $68.10 \pm 0.51 \mathrm{~cd}$ & $10.46 \pm 0.91 \mathrm{a}$ & $23.56 \pm 2.43 \mathrm{c}$ & $5.62 \pm 0.35 \mathrm{fe}$ & $39.64 \pm 1.17 \mathrm{c}$ \\
\hline Clitocybe gibba & $72.66 \pm 0.99$ & $20.68 \pm 0.15 \mathrm{f}$ & $14.59 \pm 0.27 \mathrm{k}$ & $4.29 \pm 0.00 \mathrm{~b}$ & $60.45 \pm 0.23 \mathrm{gh}$ & nd & $0.63 \pm 0.02 \mathrm{~h}$ & $1.04 \pm 0.11 \mathrm{jk}$ & $1.67 \pm 0.08 \mathrm{ji}$ \\
\hline Hygrophorus chrysodon & $92.09 \pm 1.01$ & $26.91 \pm 1.99 \mathrm{cb}$ & $15.11 \pm 0.18 \mathrm{kji}$ & $3.48 \pm 0.09 \mathrm{~cd}$ & $54.51 \pm 1.28 \mathrm{kj}$ & nd & nd & $7.27 \pm 1.40 \mathrm{e}$ & $7.27 \pm 1.40 \mathrm{hg}$ \\
\hline Lycoperdon umbrinum & $71.98 \pm 0.32$ & $33.14 \pm 1.06 \mathrm{a}$ & $14.53 \pm 0.07 \mathrm{k}$ & $0.37 \pm 0.00 \mathrm{k}$ & $51.96 \pm 0.70 \mathrm{kl}$ & nd & $0.28 \pm 0.04 \mathrm{~h}$ & $0.18 \pm 0.11 \mathrm{jk}$ & $1.46 \pm 0.07 \mathrm{ji}$ \\
\hline Suillus variegates & $90.77 \pm 0.76$ & $15.36 \pm 2.10 \mathrm{~g}$ & $17.57 \pm 0.56$ egf & $3.31 \pm 0.49 \mathrm{~cd}$ & $63.76 \pm 2.17$ ef & nd & nd & $4.85 \pm 0.28 \mathrm{fgh}$ & $4.85 \pm 0.28 \mathrm{hi}$ \\
\hline Boletus impolitus & $88.90 \pm 1.45$ & $24.43 \pm 0.84 \mathrm{ed}$ & $16.01 \pm 0.02 \mathrm{hji}$ & $2.94 \pm 0.33 \mathrm{ed}$ & $56.63 \pm 0.84 \mathrm{ij}$ & $0.31 \pm 0.01 \mathrm{e}$ & $8.08 \pm 0.08 \mathrm{~g}$ & $1.84 \pm 0.05 \mathrm{ji}$ & $10.23 \pm 0.02 \mathrm{~g}$ \\
\hline Clavariadelphus pistillaris & $84.22 \pm 1.78$ & $20.77 \pm 0.86 \mathrm{f}$ & $16.27 \pm 0.24 \mathrm{hji}$ & $0.59 \pm 0.07 \mathrm{kj}$ & $62.37 \pm 0.48 \mathrm{gf}$ & $0.93 \pm 0.22 \mathrm{c}$ & $24.43 \pm 3.25 \mathrm{c}$ & nd & $25.36 \pm 3.47 \mathrm{~d}$ \\
\hline Ramaria aurea & $88.52 \pm 0.12$ & $5.68 \pm 0.74 \mathrm{j}$ & $14.60 \pm 0.10 \mathrm{k}$ & $2.26 \pm 0.05 \mathrm{gf}$ & $77.47 \pm 0.61 \mathrm{a}$ & $1.53 \pm 0.02 b$ & $15.11 \pm 0.30$ ef & $0.95 \pm 0.11 \mathrm{jk}$ & $17.59 \pm 0.21 \mathrm{fe}$ \\
\hline Agaricus campestris & $88.17 \pm 0.44$ & $23.16 \pm 0.00 \mathrm{e}$ & $18.57 \pm 0.00$ ed & $0.11 \pm 0.00 \mathrm{k}$ & $58.16 \pm 0.00$ ih & nd & $16.94 \pm 2.71 \mathrm{ed}$ & $3.62 \pm 0.33 \mathrm{gh}$ & $20.56 \pm 3.03 \mathrm{e}$ \\
\hline Agaricus comtulus & $87.94 \pm 0.77$ & $28.14 \pm 0.18 \mathrm{cb}$ & $21.29 \pm 0.83 b$ & $0.46 \pm 0.00 \mathrm{kj}$ & $50.11 \pm 0.89 \mathrm{ml}$ & nd & $15.39 \pm 0.73 \mathrm{edf}$ & $3.60 \pm 0.06 \mathrm{gh}$ & $18.99 \pm 0.78 \mathrm{fe}$ \\
\hline Agaricus lutosus & $87.04 \pm 2.01$ & $25.96 \pm 2.64 \mathrm{~cd}$ & $23.24 \pm 0.44 \mathrm{a}$ & $1.10 \pm 0.04 \mathrm{ij}$ & $49.71 \pm 1.72 \mathrm{ml}$ & nd & $16.42 \pm 0.62 \mathrm{edf}$ & $3.35 \pm 0.19 \mathrm{ih}$ & $19.77 \pm 0.43 \mathrm{fe}$ \\
\hline Leucoagaricus leucothites & $85.29 \pm 1.00$ & $26.46 \pm 0.01 \mathrm{~cd}$ & $20.51 \pm 0.47 \mathrm{cb}$ & $1.10 \pm 0.15 \mathrm{ij}$ & $51.93 \pm 0.53 \mathrm{kl}$ & nd & $13.33 \pm 2.77 \mathrm{f}$ & $3.21 \pm 0.70 \mathrm{ih}$ & $16.54 \pm 3.47 \mathrm{f}$ \\
\hline Amanita umbrinolutea & $73.60 \pm 0.17$ & $28.86 \pm 0.00 \mathrm{cb}$ & $16.78 \pm 0.00$ hgi & $6.77 \pm 0.00 \mathrm{a}$ & $47.59 \pm 0.00 \mathrm{~m}$ & nd & $31.83 \pm 0.69 \mathrm{~b}$ & $10.06 \pm 0.58 \mathrm{~d}$ & $41.89 \pm 1.27 \mathrm{cb}$ \\
\hline Bovista aestivalis & $73.23 \pm 0.93$ & $31.86 \pm 0.20 \mathrm{a}$ & $15.59 \pm 1.23 \mathrm{ji}$ & $0.18 \pm 0.02 \mathrm{k}$ & $52.37 \pm 1.31 \mathrm{kl}$ & nd & nd & $0.38 \pm 0.08 \mathrm{k}$ & $0.38 \pm 0.08 \mathrm{j}$ \\
\hline Bovista nigrescens & $76.41 \pm 0.18$ & $3.24 \pm 0.17 \mathrm{k}$ & $20.94 \pm 0.31 b$ & $3.64 \pm 0.96 \mathrm{cb}$ & $72.18 \pm 0.76 b$ & nd & $0.93 \pm 0.01 \mathrm{~h}$ & $5.09 \pm 0.29 \mathrm{fg}$ & $6.02 \pm 0.30 \mathrm{~h}$ \\
\hline Chlorophyllum rhacodes & $88.28 \pm 0.33$ & $12.10 \pm 0.31 \mathrm{~h}$ & $19.32 \pm 0.04 \mathrm{~cd}$ & $3.29 \pm 0.33 \mathrm{~cd}$ & $65.29 \pm 0.48 \mathrm{ed}$ & nd & $18.43 \pm 0.45 \mathrm{~d}$ & $25.57 \pm 0.38 b$ & $44.00 \pm 0.07 \mathrm{~b}$ \\
\hline Clavariadelphus truncatus & $90.97 \pm 1.29$ & $12.86 \pm 0.33 \mathrm{~h}$ & $15.98 \pm 0.15 \mathrm{ji}$ & $1.54 \pm 0.25 \mathrm{ih}$ & $69.62 \pm 0.37 \mathrm{cb}$ & $0.40 \pm 0.04 \mathrm{e}$ & $43.34 \pm 2.76 \mathrm{a}$ & nd & $43.74 \pm 2.79 b$ \\
\hline Clitocybe costata & $76.92 \pm 2.11$ & $10.87 \pm 1.36 \mathrm{ih}$ & $17.27 \pm 0.25 \mathrm{hgf}$ & $1.50 \pm 0.00 \mathrm{ih}$ & $70.36 \pm 1.10 \mathrm{cb}$ & nd & $15.53 \pm 0.85$ edf & $10.99 \pm 0.54 \mathrm{~d}$ & $26.65 \pm 1.40 \mathrm{~d}$ \\
\hline Cortinarius praestans & $89.16 \pm 0.19$ & $18.89 \pm 0.01 \mathrm{f}$ & $14.56 \pm 0.24 \mathrm{k}$ & $2.58 \pm 0.28$ ef & $63.98 \pm 0.22 \mathrm{ef}$ & nd & $0.37 \pm 0.01 \mathrm{~h}$ & $60.51 \pm 2.31 \mathrm{a}$ & $60.88 \pm 2.30 \mathrm{a}$ \\
\hline Flammulina velutipes & $90.68 \pm 0.58$ & $9.42 \pm 0.66 \mathrm{i}$ & $17.89 \pm 0.02 \mathrm{egf}$ & $1.84 \pm 0.14 \mathrm{gh}$ & $70.85 \pm 0.36 \mathrm{cb}$ & nd & $5.98 \pm 1.19 \mathrm{~g}$ & $15.08 \pm 1.60 \mathrm{c}$ & $24.61 \pm 3.05 \mathrm{~d}$ \\
\hline
\end{tabular}

nd- not detected. In each column, different letters mean significant differences between species $(p<0.05)$. 
Table 3. Main fatty acids (percentage) found in the wild edible mushrooms.

\begin{tabular}{|c|c|c|c|c|c|c|c|}
\hline & C16:0 & C18:0 & C18:1n9 & C18:2n6 & SFA & MUFA & PUFA \\
\hline Boletus armeniacus & $15.68 \pm 0.34$ ef & $2.92 \pm 0.20 \mathrm{~g}$ & $27.61 \pm 0.42 \mathrm{f}$ & $48.95 \pm 0.06 \mathrm{f}$ & $21.01 \pm 0.27 \mathrm{gh}$ & $29.67 \pm 0.36 \mathrm{f}$ & $49.32 \pm 0.09 \mathrm{e}$ \\
\hline Clitocybe gibba & $13.81 \pm 0.16 \mathrm{~g}$ & $7.89 \pm 0.03 \mathrm{a}$ & $4.91 \pm 0.18 \mathrm{lk}$ & $64.45 \pm 0.15 c$ & $27.82 \pm 0.14 \mathrm{~d}$ & $6.16 \pm 0.10 \mathrm{ml}$ & $66.02 \pm 0.24 \mathrm{c}$ \\
\hline Hygrophorus chrysodon & $25.95 \pm 0.61 \mathrm{a}$ & $3.88 \pm 0.01 \mathrm{e}$ & $57.26 \pm 0.57 \mathrm{a}$ & $1.23 \pm 0.06 \mathrm{~m}$ & $35.32 \pm 0.67 \mathrm{c}$ & $63.05 \pm 0.55 \mathrm{a}$ & $1.63 \pm 0.13 \mathrm{k}$ \\
\hline Lycoperdon umbrinum & $19.92 \pm 0.12 \mathrm{c}$ & $7.14 \pm 0.5 b$ & $22.83 \pm 0.33 \mathrm{~g}$ & $29.36 \pm 0.11 \mathrm{j}$ & $42.48 \pm 0.49 a$ & $24.79 \pm 0.77 \mathrm{~g}$ & $32.74 \pm 0.19 h$ \\
\hline Suillus variegates & $12.71 \pm 0.29$ hgi & $3.47 \pm 0.08 \mathrm{f}$ & $42.00 \pm 0.26 \mathrm{~d}$ & $37.44 \pm 0.13 \mathrm{~h}$ & $18.09 \pm 0.29 \mathrm{j}$ & $44.24 \pm 0.16 \mathrm{~d}$ & $37.67 \pm 0.12 \mathrm{~g}$ \\
\hline Boletus impolitus & $16.77 \pm 0.40 \mathrm{~d}$ & $1.10 \pm 0.161$ & $14.21 \pm 1.45 \mathrm{ji}$ & $60.95 \pm 1.10 \mathrm{~d}$ & $23.19 \pm 0.41 \mathrm{f}$ & $15.48 \pm 1.42 \mathrm{j}$ & $61.33 \pm 1.01 \mathrm{~d}$ \\
\hline Clavariadelphus pistillaris & $16.76 \pm 0.81 \mathrm{~d}$ & $3.99 \pm 0.07 \mathrm{ed}$ & $49.11 \pm 0.23 b$ & $24.74 \pm 0.82 \mathrm{k}$ & $24.86 \pm 0.84 \mathrm{e}$ & $50.11 \pm 0.02 \mathrm{c}$ & $25.03 \pm 0.86 \mathrm{i}$ \\
\hline Ramaria aurea & $7.32 \pm 0.04 \mathrm{k}$ & $4.07 \pm 0.09 \mathrm{ed}$ & $56.92 \pm 0.49 \mathrm{a}$ & $25.60 \pm 0.17 \mathrm{k}$ & $15.27 \pm 0.23 \mathrm{k}$ & $58.47 \pm 0.40 \mathrm{~b}$ & $26.26 \pm 0.17 \mathrm{i}$ \\
\hline Agaricus campestris & $12.48 \pm 0.01 \mathrm{hi}$ & $2.73 \pm 0.01 \mathrm{~g}$ & $6.09 \pm 0.01 \mathrm{k}$ & $68.97 \pm 0.07 b$ & $20.91 \pm 0.05 \mathrm{gh}$ & $9.05 \pm 0.03 \mathrm{k}$ & $70.04 \pm 0.02 b$ \\
\hline Agaricus comtulus & $12.98 \pm 0.35$ hgi & $2.66 \pm 0.03 \mathrm{~g}$ & $3.50 \pm 0.011$ & $72.88 \pm 0.57 \mathrm{a}$ & $22.04 \pm 0.63 \mathrm{gf}$ & $4.42 \pm 0.04 \mathrm{~m}$ & $73.55 \pm 0.59 \mathrm{a}$ \\
\hline Agaricus lutosus & $12.03 \pm 0.01 \mathrm{i}$ & $2.26 \pm 0.22 \mathrm{~h}$ & $6.11 \pm 0.85 \mathrm{k}$ & $74.40 \pm 0.19 a$ & $18.49 \pm 0.53 \mathrm{ij}$ & $6.63 \pm 0.831$ & $74.88 \pm 0.30 \mathrm{a}$ \\
\hline Leucoagaricus leucothites & $12.16 \pm 0.20 \mathrm{i}$ & $1.81 \pm 0.11 \mathrm{ij}$ & $6.27 \pm 0.39 \mathrm{k}$ & $74.72 \pm 1.32 \mathrm{a}$ & $18.00 \pm 0.84 \mathrm{j}$ & $6.74 \pm 0.431$ & $75.25 \pm 1.27 \mathrm{a}$ \\
\hline Amanita umbrinolutea & $15.10 \pm 0.13 \mathrm{f}$ & $3.87 \pm 0.01 \mathrm{e}$ & $58.82 \pm 0.08 \mathrm{a}$ & $18.81 \pm 0.021$ & $21.18 \pm 0.10 \mathrm{gh}$ & $59.82 \pm 0.12 b$ & $19.00 \pm 0.02 \mathrm{j}$ \\
\hline Bovista aestivalis & $21.43 \pm 1.70 \mathrm{~b}$ & $4.32 \pm 0.24 \mathrm{~d}$ & $12.63 \pm 0.13 j$ & $41.51 \pm 3.75 \mathrm{~g}$ & $41.80 \pm 2.72 \mathrm{a}$ & $15.53 \pm 1.20 \mathrm{j}$ & $42.68 \pm 3.92 \mathrm{f}$ \\
\hline Bovista nigrescens & $17.39 \pm 0.07 \mathrm{~d}$ & $4.19 \pm 0.26 \mathrm{ed}$ & $21.01 \pm 0.24 \mathrm{~h}$ & $38.28 \pm 0.17 \mathrm{~h}$ & $37.78 \pm 0.47 b$ & $23.16 \pm 0.26 \mathrm{hg}$ & $39.06 \pm 0.21 \mathrm{~g}$ \\
\hline Chlorophyllum rhacodes & $16.35 \pm 0.31 \mathrm{ed}$ & $1.59 \pm 0.03 \mathrm{kj}$ & $5.68 \pm 0.06 \mathrm{k}$ & $72.61 \pm 0.51 \mathrm{a}$ & $20.11 \pm 0.35 \mathrm{ih}$ & $6.91 \pm 0.021$ & $72.98 \pm 0.36 \mathrm{a}$ \\
\hline Clavariadelphus truncatus & $14.80 \pm 0.18 \mathrm{f}$ & $2.11 \pm 0.01 \mathrm{ih}$ & $47.26 \pm 0.02 \mathrm{c}$ & $29.77 \pm 0.12 \mathrm{j}$ & $21.43 \pm 0.06 \mathrm{gh}$ & $48.31 \pm 0.07 \mathrm{c}$ & $30.26 \pm 0.02 \mathrm{~h}$ \\
\hline Clitocybe costata & $12.76 \pm 0.07 \mathrm{hgi}$ & $5.99 \pm 0.18 \mathrm{c}$ & $37.27 \pm 0.20 \mathrm{e}$ & $34.68 \pm 0.92 \mathrm{i}$ & $22.34 \pm 0.41 \mathrm{gf}$ & $38.02 \pm 0.31 \mathrm{e}$ & $39.64 \pm 0.87 \mathrm{~g}$ \\
\hline Cortinarius praestans & $13.44 \pm 0.03 \mathrm{hg}$ & $1.78 \pm 0.41 \mathrm{j}$ & $20.76 \pm 3.04 \mathrm{~h}$ & $59.95 \pm 3.33 \mathrm{~d}$ & $17.93 \pm 0.67 \mathrm{j}$ & $21.49 \pm 3.09 \mathrm{~h}$ & $60.59 \pm 3.76 \mathrm{~d}$ \\
\hline Flammulina velutipes & $10.31 \pm 0.39 \mathrm{j}$ & $1.38 \pm 0.08 \mathrm{kl}$ & $15.08 \pm 0.47 \mathrm{i}$ & $56.33 \pm 0.14 \mathrm{e}$ & $14.36 \pm 0.34 \mathrm{k}$ & $17.56 \pm 0.51 \mathrm{i}$ & $68.08 \pm 0.17 \mathrm{cb}$ \\
\hline
\end{tabular}

Palmitic acid (C16:0); Stearic acid (C18:0); Oleic acid (C18:1n9c); Linoleic acid (C18:2n6c); SFAsaturated fatty acids; MUFA- monounsaturated fatty acids; PUFA- polyunsaturated fatty acids. The results are expressed in percentage. The difference to $100 \%$ corresponds to other 23 less abundant fatty acids (data not shown). In each column different letters mean significant differences between species $(p<0.05)$. 
Table 4. Micronutrients composition of the wild edible mushrooms.

\begin{tabular}{|c|c|c|c|c|c|c|c|c|}
\hline & $\alpha$-tocopherol & $\beta$-tocopherol & $\gamma$-tocopherol & $\delta$-tocopherol & $\begin{array}{l}\text { Total tocopherols } \\
(\mathrm{mg} / 100 \mathrm{~g} \mathrm{dw})\end{array}$ & $\begin{array}{c}\text { Ascorbic acid } \\
(\mathrm{mg} / 100 \mathrm{~g} \mathrm{dw})\end{array}$ & $\begin{array}{c}\beta \text {-carotene } \\
(\mathrm{mg} / 100 \mathrm{~g} \mathrm{dw})\end{array}$ & $\begin{array}{c}\text { Lycopene } \\
(\mathrm{mg} / 100 \mathrm{~g} \mathrm{dw})\end{array}$ \\
\hline Boletus armeniacus & $0.01 \pm 0.00 \mathrm{c}$ & $0.03 \pm 0.00 \mathrm{c}$ & $0.03 \pm 0.00 \mathrm{fe}$ & $\mathrm{nq}$ & $0.07 \pm 0.00 \mathrm{hg}$ & nd & $0.15 \pm 0.00 \mathrm{k}$ & nd \\
\hline Clitocybe gibba & $0.03 \pm 0.00 \mathrm{c}$ & nd & $0.19 \pm 0.01 \mathrm{~b}$ & nd & $0.22 \pm 0.02 \mathrm{~d}$ & $19.47 \pm 1.62 \mathrm{~d}$ & nd & $0.09 \pm 0.00 \mathrm{~d}$ \\
\hline Hygrophorus chrysodon & $\mathrm{nq}$ & $0.01 \pm 0.00 \mathrm{~d}$ & nd & $0.01 \pm 0.00 \mathrm{ed}$ & $0.02 \pm 0.00 \mathrm{i}$ & $33.16 \pm 0.57 \mathrm{a}$ & $0.43 \pm 0.01 \mathrm{~d}$ & nd \\
\hline Lycoperdon umbrinum & $1.48 \pm 0.01 \mathrm{a}$ & $0.10 \pm 0.00 \mathrm{a}$ & $0.07 \pm 0.00 \mathrm{c}$ & $0.02 \pm 0.00 \mathrm{c}$ & $1.67 \pm 0.01 \mathrm{a}$ & nd & $0.17 \pm 0.00 \mathrm{j}$ & nd \\
\hline Suillus variegatus & $0.02 \pm 0.00 \mathrm{c}$ & nd & $1.44 \pm 0.03 \mathrm{a}$ & $\mathrm{nq}$ & $1.45 \pm 0.03 \mathrm{~b}$ & $6.39 \pm 0.22 \mathrm{f}$ & nd & $0.27 \pm 0.00 \mathrm{c}$ \\
\hline Boletus impolitus & $\mathrm{nq}$ & $0.01 \pm 0.00 \mathrm{~d}$ & $0.06 \pm 0.01 \mathrm{dc}$ & $\mathrm{nq}$ & $0.07 \pm 0.01 \mathrm{hg}$ & $1.99 \pm 0.54 \mathrm{~h}$ & $0.29 \pm 0.01 \mathrm{~g}$ & nd \\
\hline Clavariadelphus pistillaris & $\mathrm{nq}$ & $0.02 \pm 0.00 \mathrm{dc}$ & nd & $0.01 \pm 0.00 \mathrm{e}$ & $0.03 \pm 0.00 \mathrm{hi}$ & $3.45 \pm 0.20 \mathrm{~g}$ & $0.08 \pm 0.00 \mathrm{~m}$ & $0.04 \pm 0.00 \mathrm{~g}$ \\
\hline Ramaria aurea & $0.01 \pm 0.00 \mathrm{c}$ & $0.10 \pm 0.00 \mathrm{a}$ & $0.03 \pm 0.01 \mathrm{fe}$ & $0.01 \pm 0.00 \mathrm{e}$ & $0.15 \pm 0.01 \mathrm{fe}$ & $0.66 \pm 0.07 \mathrm{i}$ & nd & $0.51 \pm 0.00 \mathrm{a}$ \\
\hline Agaricus campestris & $0.01 \pm 0.00 \mathrm{c}$ & $0.03 \pm 0.01 \mathrm{c}$ & $0.04 \pm 0.00 \mathrm{de}$ & $0.03 \pm 0.00 \mathrm{cb}$ & $0.11 \pm 0.01 \mathrm{fg}$ & $18.74 \pm 1.09 \mathrm{~d}$ & $0.60 \pm 0.00 \mathrm{a}$ & nd \\
\hline Agaricus comtulus & $0.01 \pm 0.00 \mathrm{c}$ & $0.06 \pm 0.00 \mathrm{~b}$ & $0.03 \pm 0.00 \mathrm{fe}$ & $0.07 \pm 0.01 \mathrm{a}$ & $0.17 \pm 0.01 \mathrm{e}$ & nd & $0.59 \pm 0.01 \mathrm{~b}$ & nd \\
\hline Agaricus lutosus & nq & $0.01 \pm 0.00 \mathrm{dc}$ & $0.01 \pm 0.00 \mathrm{f}$ & $0.04 \pm 0.00 \mathrm{~b}$ & $0.07 \pm 0.01 \mathrm{hg}$ & $32.18 \pm 0.20 \mathrm{a}$ & nd & $0.44 \pm 0.00 \mathrm{~b}$ \\
\hline Leucoagaricus leucothites & $\mathrm{nq}$ & nd & $0.01 \pm 0.00 \mathrm{f}$ & $0.03 \pm 0.00 \mathrm{c}$ & $0.04 \pm 0.00 \mathrm{hi}$ & $18.87 \pm 0.26 \mathrm{~d}$ & $0.40 \pm 0.01 \mathrm{e}$ & nd \\
\hline Amanita umbrinolutea & $0.01 \pm 0.00 \mathrm{c}$ & $0.03 \pm 0.00 \mathrm{c}$ & nd & $0.01 \pm 0.00 \mathrm{ed}$ & $0.05 \pm 0.00 \mathrm{hi}$ & $22.73 \pm 1.91 \mathrm{c}$ & $0.56 \pm 0.00 \mathrm{c}$ & nd \\
\hline Bovista aestivalis & $\mathrm{nq}$ & $\mathrm{nq}$ & $0.04 \pm 0.00 \mathrm{de}$ & $\mathrm{nq}$ & $0.04 \pm 0.00 \mathrm{hi}$ & nd & $0.05 \pm 0.00 \mathrm{n}$ & nd \\
\hline Bovista nigrescens & $\mathrm{nq}$ & $0.02 \pm 0.00 \mathrm{dc}$ & nd & nd & $0.02 \pm 0.00 \mathrm{i}$ & nd & $0.21 \pm 0.00 \mathrm{i}$ & nd \\
\hline Chlorophyllum rhacodes & $\mathrm{nq}$ & $0.02 \pm 0.00 \mathrm{dc}$ & nd & $0.01 \pm 0.00 \mathrm{ed}$ & $0.03 \pm 0.00 \mathrm{hi}$ & nd & $0.15 \pm 0.00 \mathrm{k}$ & nd \\
\hline Clavariadelphus truncatus & $0.02 \pm 0.00 \mathrm{c}$ & $\mathrm{nq}$ & $0.04 \pm 0.01 \mathrm{de}$ & $0.01 \pm 0.00 \mathrm{ed}$ & $0.07 \pm 0.01 \mathrm{hg}$ & $7.14 \pm 0.13 \mathrm{f}$ & $0.11 \pm 0.011$ & $0.07 \pm 0.00 \mathrm{e}$ \\
\hline Clitocybe costata & $0.48 \pm 0.06 b$ & $0.03 \pm 0.01 \mathrm{c}$ & nd & nd & $0.51 \pm 0.07 \mathrm{c}$ & nd & $0.07 \pm 0.00 \mathrm{~m}$ & $0.03 \pm 0.00 \mathrm{~h}$ \\
\hline Cortinarius praestans & nq & $0.02 \pm 0.00 \mathrm{dc}$ & $0.03 \pm 0.01 \mathrm{fe}$ & $0.01 \pm 0.00 \mathrm{e}$ & $0.06 \pm 0.01 \mathrm{hi}$ & $9.06 \pm 1.33 \mathrm{e}$ & $0.26 \pm 0.00 \mathrm{~h}$ & $0.06 \pm 0.00 \mathrm{f}$ \\
\hline Flammulina velutipes & $0.01 \pm 0.00 \mathrm{c}$ & $0.03 \pm 0.00 \mathrm{c}$ & nd & $0.02 \pm 0.00 \mathrm{~cd}$ & $0.06 \pm 0.00$ hgi & $23.87 \pm 0.38 b$ & $0.34 \pm 0.00 \mathrm{f}$ & $0.02 \pm 0.00 \mathrm{i}$ \\
\hline
\end{tabular}

nd- not detected; nq- not quantifiable. In each column different letters mean significant differences between species $(p<0.05)$. 
Table 5. Non-nutrients composition and in vitro antioxidant properties ( $\mathrm{EC}_{50}$ values) of the wild edible mushrooms.

\begin{tabular}{|c|c|c|c|c|c|}
\hline & $\begin{array}{l}\text { Phenolics } \\
\text { (mg GAE/g extract) }\end{array}$ & $\begin{array}{l}\text { Flavonoids } \\
\text { (mg CE/g extract) }\end{array}$ & $\begin{array}{l}\text { DPPH scavenging activity } \\
(\mathrm{mg} / \mathrm{ml})\end{array}$ & $\begin{array}{l}\text { Reducing power } \\
(\mathrm{mg} / \mathrm{ml})\end{array}$ & $\begin{array}{l}\beta \text {-carotene bleaching inhibition } \\
(\mathrm{mg} / \mathrm{ml})\end{array}$ \\
\hline Boletus armeniacus & $44.66 \pm 1.65 \mathrm{c}$ & $8.59 \pm 0.28 \mathrm{~d}$ & $1.74 \pm 0.10 \mathrm{kl}$ & $0.63 \pm 0.02 \mathrm{lk}$ & $0.77 \pm 0.09 \mathrm{~h}$ \\
\hline Clitocybe gibba & $25.26 \pm 1.15 \mathrm{ed}$ & $3.56 \pm 0.79 \mathrm{ih}$ & $10.61 \pm 1.08 \mathrm{cb}$ & $1.46 \pm 0.27 \mathrm{~g}$ & $4.00 \pm 0.51 \mathrm{cb}$ \\
\hline Hygrophorus chrysodon & $4.58 \pm 1.12 \mathrm{j}$ & $1.78 \pm 0.08 \mathrm{i}$ & $20.02 \pm 1.27 \mathrm{a}$ & $7.82 \pm 0.03 \mathrm{a}$ & $5.95 \pm 0.50 \mathrm{a}$ \\
\hline Lycoperdon umbrinum & $27.02 \pm 0.17 \mathrm{~d}$ & $3.82 \pm 0.24 \mathrm{ihg}$ & $3.45 \pm 0.09 \mathrm{hg}$ & $1.27 \pm 0.06 \mathrm{ih}$ & $3.24 \pm 0.70 \mathrm{~cd}$ \\
\hline Suillus variegatus & $58.14 \pm 4.51 \mathrm{a}$ & $33.00 \pm 4.98 \mathrm{a}$ & $0.86 \pm 0.02 \mathrm{~m}$ & $0.52 \pm 0.011$ & $1.00 \pm 0.15 \mathrm{~h}$ \\
\hline Boletus impolitus & $15.50 \pm 0.53 \mathrm{~g}$ & $3.72 \pm 0.22$ ih & $5.81 \pm 0.17 \mathrm{ed}$ & $2.04 \pm 0.01 \mathrm{e}$ & $2.04 \pm 0.44 \mathrm{f}$ \\
\hline Clavariadelphus pistillaris & $48.10 \pm 0.76 \mathrm{cb}$ & $18.61 \pm 0.85 b$ & $1.30 \pm 0.07 \mathrm{ml}$ & $0.70 \pm 0.00 \mathrm{k}$ & $1.94 \pm 0.02 \mathrm{fg}$ \\
\hline Ramaria aurea & $8.46 \pm 0.41 \mathrm{ji}$ & $2.44 \pm 0.46 \mathrm{i}$ & $3.70 \pm 0.11 \mathrm{~g}$ & $0.99 \pm 0.02 \mathrm{j}$ & $2.46 \pm 0.40$ fde \\
\hline Agaricus campestris & $20.94 \pm 4.98$ ef & $5.59 \pm 0.29$ ehgf & $5.48 \pm 0.08$ ed & $2.70 \pm 0.23 \mathrm{c}$ & $4.59 \pm 1.30 \mathrm{~b}$ \\
\hline Agaricus comtulus & $24.13 \pm 7.98 \mathrm{ed}$ & $3.76 \pm 0.94 \mathrm{ihg}$ & $2.22 \pm 0.05 \mathrm{kji}$ & $1.29 \pm 0.01 \mathrm{ih}$ & $1.08 \pm 0.05 \mathrm{hg}$ \\
\hline Agaricus lutosus & $46.56 \pm 4.16 \mathrm{cb}$ & $7.67 \pm 0.90 \mathrm{ed}$ & $2.54 \pm 0.44 \mathrm{kji}$ & $0.91 \pm 0.02 \mathrm{j}$ & $0.90 \pm 0.10 \mathrm{~h}$ \\
\hline Leucoagaricus leucothites & $15.75 \pm 1.98 \mathrm{~g}$ & $2.43 \pm 0.69 \mathrm{i}$ & $11.33 \pm 1.05 \mathrm{~b}$ & $3.28 \pm 0.05 \mathrm{~b}$ & $1.00 \pm 0.21 \mathrm{~h}$ \\
\hline Amanita umbrinolutea & $9.22 \pm 0.16 \mathrm{hji}$ & $6.54 \pm 0.25 \mathrm{edf}$ & $10.02 \pm 0.34 \mathrm{c}$ & $2.71 \pm 0.04 \mathrm{c}$ & $3.69 \pm 0.70 \mathrm{c}$ \\
\hline Bovista aestivalis & $50.91 \pm 1.97 \mathrm{~b}$ & $8.51 \pm 0.43 \mathrm{~d}$ & $2.05 \pm 0.10 \mathrm{kjl}$ & $0.51 \pm 0.011$ & $0.61 \pm 0.02 \mathrm{~h}$ \\
\hline Bovista nigrescens & $26.50 \pm 1.18 \mathrm{~d}$ & $14.10 \pm 0.70 \mathrm{c}$ & $4.62 \pm 0.44 \mathrm{f}$ & $1.21 \pm 0.02 \mathrm{i}$ & $1.91 \pm 0.22 \mathrm{fg}$ \\
\hline Chlorophyllum rhacodes & $22.77 \pm 5.26 \mathrm{edf}$ & $2.63 \pm 0.13 \mathrm{i}$ & $5.32 \pm 0.06$ ef & $2.22 \pm 0.01 \mathrm{~d}$ & $2.33 \pm 0.41 \mathrm{fe}$ \\
\hline Clavariadelphus truncatus & $7.66 \pm 1.37 \mathrm{j}$ & $5.82 \pm 0.36 \mathrm{egf}$ & $2.74 \pm 0.04 \mathrm{hji}$ & $1.33 \pm 0.05 \mathrm{~h}$ & $2.35 \pm 0.20 \mathrm{fde}$ \\
\hline Clitocybe costata & $13.71 \pm 1.30 \mathrm{hg}$ & $4.80 \pm 0.35 \mathrm{hgf}$ & $10.56 \pm 0.55 \mathrm{cb}$ & $1.66 \pm 0.01 \mathrm{f}$ & $3.22 \pm 0.60 \mathrm{~cd}$ \\
\hline Cortinarius praestans & $17.81 \pm 0.83 \mathrm{gf}$ & $5.46 \pm 0.52 \mathrm{hgf}$ & $3.04 \pm 0.08$ hgi & $1.70 \pm 0.01 \mathrm{f}$ & $2.04 \pm 0.44 \mathrm{f}$ \\
\hline Flammulina velutipes & $12.98 \pm 0.32$ hgi & $2.46 \pm 0.20 \mathrm{i}$ & $6.19 \pm 0.17 \mathrm{~d}$ & $1.94 \pm 0.01 \mathrm{e}$ & $1.12 \pm 0.23 \mathrm{hg}$ \\
\hline
\end{tabular}

In each column different letters mean significant differences between species $(p<0.05)$. 

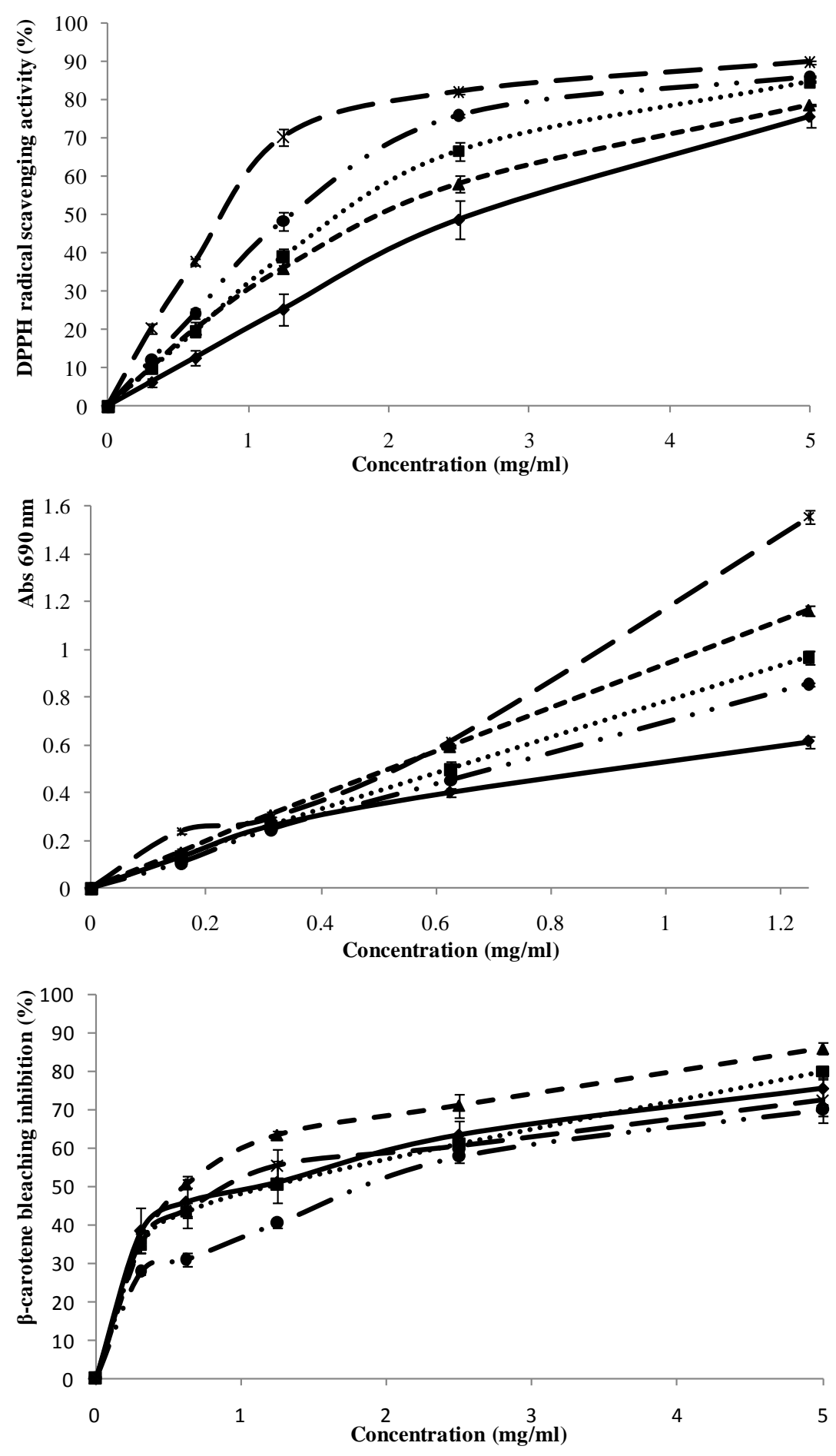

Figure 1. DPPH scavenging activity, reducing power and $\beta$-carotene bleaching inhibition of the five mushrooms with lowest $\mathrm{EC}_{50}$ values (highest antioxidant properties): - $\mathbf{- \Delta B}$ Boletus armeniacus (Castanea sativa habitat), $\rightarrow$ Clavariadelphus pistillaris (Quercus sp. habitat), $\longrightarrow$ Agaricus lutosus (fields), $\cdots \cdot \cdots$ Bovista aestivalis (mixed stands) and $\rightarrow$ Suillus variegatus ( Pinus sp). 


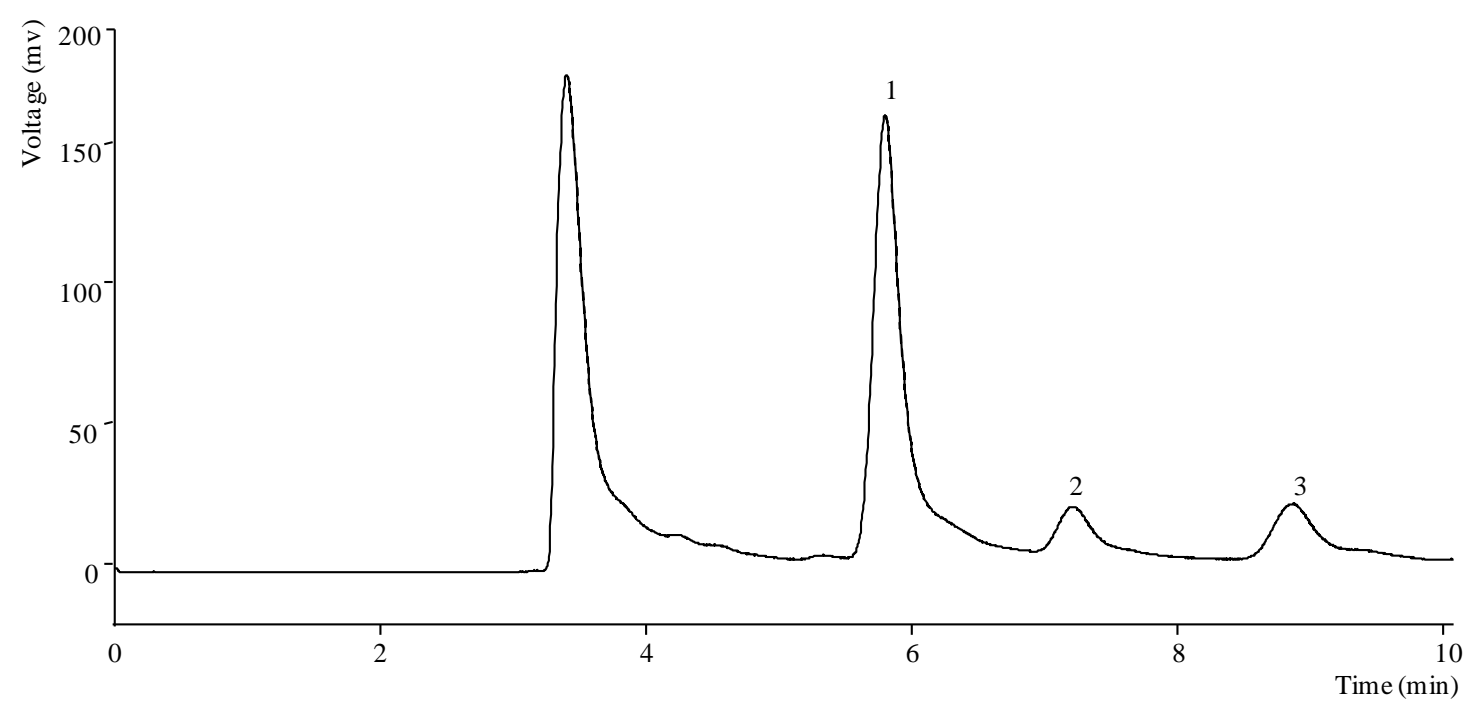

Figure 2. Individual sugars chromatogram of Agaricus campestris: 1-mannitol; 2trehalose; 3-raffinose (IS). 